\title{
Spatial and temporal assessment of climate impact on agriculture in plateau region, India
}

\author{
NAVEEN P. SINGH ${ }^{1 *}$, BHAWNAANAND ${ }^{1}$, K.V. RAO ${ }^{2}$ and RANJITH P.C. ${ }^{3}$ \\ ${ }^{1} I C A R$-National Institute of Agricultural Economics \& Policy Research (NIAP), New Delhi; \\ ${ }^{2} I C A R$-Central Research Institute for Dryland Agriculture (CRIDA), Hyderabad; \\ ${ }^{3}$ ICAR-Indian Agricultural Research Institute (IARI), New Delhi \\ *Corresponding author: naveenpsingh@gmail.com
}

\begin{abstract}
Using large-scale district-level data, the study examined the impact of climate change on crop yields during the period 1966-2011and predictsthe likely changes in yield sacross agro-climatic zones in Plateau Region. The future projections reveal that by 2080s, cotton yield is expected to decline by 7.18 percent in Western Plateau \& Hills.By the end of the century, sorghum yield is projected to decline up to 19 percent in Central Plateau \& Hills and increase by 18 percent in Western Plateau \& Hills. Under midterm period, rapeseed \& mustard yield is likely to reduce by 3.44 percent in Western Plateau \& Hills. By 2050s maize yield is expected to reduce by 3.33 percent in Central Plateau \& Hills. By 2080s, wheat yield is projected to decline by 5.44 , percent in SouthernPlateau \& Hills. The results suggest that impact of climate change on crop yield varies across regions, hence it is pertinent to formulate adaptation strategies and farm practices suitable to the crop and location specific needs that mitigate the likely exposure of food production and livelihoods to climate variations.
\end{abstract}

Keywords: Crop yields, climate change, agro-climatic zones, impact, projections

Climate change is one of the prominent factors that directly affect agriculture production and farm livelihoods. Changes in rainfall and temperature are expected to adversely impact crop yields, thus posing significant threat to the food production (Nelson et al., 2010;Bal and Minhas, 2017,Balvanshi and Tiwari, 2019).Under different climate scenarios several studies that examined the impact of change in rainfall and temperatures on crop yields indicate a decline in rice, wheat and maize in the country (Guiteras, 2009). However, regional differences in terms of agro-climatic conditions, farm centric adaptation measures, economic and institutional capacities, regulate the vulnerability of agriculture to climatic variations. This produces spatial differentials inthe magnitude of the climate impact on agriculture production and productivity (Singh et al., 2019). Understanding the sensitivity of agriculture productivity to climate change is thus, a prelude in developing informed technologies (Jalota et al., 2013) and programs that ameliorate the likely effects of climate change.Most of the previous assessments have extrapolated climate impact on crop yields at a national and state level; however, there remains a considerable uncertainty over the likely climate impact for homologous environments. Building on these considerations, the present study aims to assess the impact of climate change on major kharif and rabi crops, across agro-climatic zones(ACZs) in Plateau Region during the period 1966-2011 and projects the likely changes in crop yield for three time periods (2030s, 2050s, and 2080s).

\section{METHODS AND MATERIALS}

\section{Study area}

The Plateau Region covers about 44.19 percent of the country's total geographical area, with 33.91 percent population residing in rural areas. Rice, maize, wheat ragi, bajra, gram, jowar, and groundnut are some of the major crops grown in the region. Plateau region consist of four ACZs namely, Eastern Plateau \& Hills, Central Plateau \& Hills, Western Plateau \& Hills and Southern Plateau \& Hills. The annual rainfall in the region varies from $843.24 \mathrm{~mm}$ in Southern Plateau \& Hills to $1324.19 \mathrm{~mm}$ in the Eastern Plateau \& Hills. Among the zones, Western Plateau \& Hills (covering parts of Madhya Pradesh and Maharashtra) have the largest net sown area of 19.66 million hectares, while Eastern Plateau \& Hills covers the lowest area of 10.46 million hectares. In terms of food grain yield, Southern Plateau \& Hills registered high yield of 2.72 tonha $^{-1}$, followed by Central Plateau \& Hills (1.95 tonha $\left.{ }^{-1}\right)($ Table 1$)$. 
Table 1: Spatial characteristics of Plateau and Hills Region

\begin{tabular}{|c|c|c|c|c|}
\hline Variables & $\begin{array}{l}\text { Eastern Plateau } \\
\& \text { Hills }\end{array}$ & $\begin{array}{l}\text { Central Plateau } \\
\& \text { Hills }\end{array}$ & $\begin{array}{l}\text { Western Plateau } \\
\& \text { Hills }\end{array}$ & $\begin{array}{l}\text { Southern Plateau } \\
\& \text { Hills }\end{array}$ \\
\hline Climate & $\begin{array}{l}\text { Moist Sub-Humid to } \\
\text { Dry Sub-Humid }\end{array}$ & $\begin{array}{l}\text { Semi-Arid to } \\
\text { Dry Sub-Humid }\end{array}$ & Semi-Arid & Semi-Arid \\
\hline Annual Rainfall (mm) (1966-2011) & 1324.19 & 916.80 & 929.05 & 843.24 \\
\hline Annual $\operatorname{MinT}\left({ }^{\circ} \mathrm{C}\right)(1996-2011)$ & 19.95 & 19.13 & 19.95 & 21.41 \\
\hline Annual MaxT $\left({ }^{\circ} \mathrm{C}\right)(1966-2011)$ & 31.42 & 32.00 & 32.91 & 32.23 \\
\hline States & $\begin{array}{l}\text { Chhattisgarh, } \\
\text { Jharkhand, } \\
\text { Madhya Pradesh, } \\
\text { Maharashtra, Odisha, } \\
\text { West Bengal }\end{array}$ & $\begin{array}{l}\text { Madhya Pradesh, } \\
\text { Rajasthan, } \\
\text { Uttar Pradesh }\end{array}$ & $\begin{array}{l}\text { Madhya Pradesh, } \\
\text { Maharashtra }\end{array}$ & $\begin{array}{l}\text { Andhra Pradesh, } \\
\text { Karnataka, } \\
\text { Tamil Nadu }\end{array}$ \\
\hline Net Sown Area (Mha) & 10.46 & 16.78 & 19.66 & 18.08 \\
\hline Food grains yield $\left(\right.$ Tonha $\left.^{-1}\right)$ & 1.56 & 1.95 & 1.56 & 2.72 \\
\hline Major Crops & $\begin{array}{l}\text { Rice, Wheat, } \\
\text { Maize, Ragi }\end{array}$ & $\begin{array}{l}\text { Rice, Wheat, } \\
\text { Maize, Ragi }\end{array}$ & $\begin{array}{l}\text { Wheat, Gram, } \\
\text { Jowar, Rice, Bajra }\end{array}$ & $\begin{array}{l}\text { Jowar, Rice, } \\
\text { Ragi, Groundnut }\end{array}$ \\
\hline
\end{tabular}

Source: Authors Estimation and compilation.Census of India (2011), Singh (2006), Directorate of Economics and Statistics, Ministry of Agriculture and Farmers'Welfare, and India Meteorological Department, Government of India.

Table 2: Projected changes in annual mean daily minimum and maximum temperature over India

\begin{tabular}{lllll}
\hline Variable & Scenarios & Near-term(2030s) & Mid-term(2050s) & Long-term(2080s) \\
\hline Minimum temperature & RCP 8.5 & $1.50 \pm 0.16(10.7 \%)$ & $2.60 \pm 0.23(8.8 \%)$ & $4.43 \pm 0.34(7.7 \%)$ \\
Maximum temperature & RCP 8.5 & $1.36 \pm 0.16(11.8 \%)$ & $2.30 \pm 0.31(13.5 \%)$ & $3.94 \pm 0.45(11.4 \%)$ \\
\hline
\end{tabular}

Figure in the parenthesis indicate the associated uncertainty range

Source: Climate Change over India: An Interim report (2017). Centre for Climate Change Research, ESSO-IITM, Ministry of Earth Sciences, Govt. of India.

\section{Data Source}

The present study used district-level data on area and production of crops and certain control factors (i.e., irrigated area, road length, literacy, number of tractors and pump sets, and fertilizer consumption) during the period 1966-2011, extracted from International Crops Research Institute for the Semi-Arid Tropics (ICRISAT) database. The data on rainfall and temperatures was collected from the India Meteorological Department, Government of India and wasaggregated into crop growing periods, i.e., sowing, germination and harvesting for impact assessment.

\section{Estimation Method}

The present study used the following model specification to assess climate impact on crop yield,

$\log Y_{d t}=c+a_{d}+\partial t+\gamma \log X_{d t}+\beta \log W_{d t}+\epsilon_{d t} \ldots$.
Where, $Y_{d t}$ represents crop yield, $W_{d t}$ is a vector of climate parameters (rainfall, minimum and maximum temperatures), $X_{d t}$ denote control factors and $\epsilon_{d t}$ is the error term for the $d^{\text {th }}$ district during the $t^{\text {th }}$ time period. The model includes district-level fixed effects, $a_{d}$ which controls for unobserved district-specific heterogeneity variable to eliminate the omitted variables bias. Further, a time trend $(t)$ has been incorporated in the model, as a proxy to absorb the technological effects and other farm-level adaptation strategies.

In order to ensure the robustness of the applied panel regression, certain residual diagnostics tests were employed. We tested for the first-order autocorrelation in the residuals of a linear panel-data using the Wooldridge test (Woolridge, 2002). The homoscedasticity of the error process across 
Table 3: Estimated regression coefficients of climate impact on crop yields: Eastern Plateau \& Hills

\begin{tabular}{|c|c|c|c|c|}
\hline Variables & Rice & Maize & Wheat & linseed \\
\hline Ln Rainfall & $0.0461 * * *(0.0066)$ & $-0.0048(0.0120)$ & $-0.0061 * * *(0.0013)$ & $0.0109 * * *(0.0040)$ \\
\hline Ln Min Temp & $-0.0667(0.1042)$ & $-0.1775(0.1434)$ & $-0.0433(0.0469)$ & $-0.7519 * * *(0.1464)$ \\
\hline Ln Max Temp & $-0.1508(0.1055)$ & $0.3688^{* * *}(0.1244)$ & $0.0322(0.0603)$ & $0.3390 *(0.1895)$ \\
\hline Ln Irrigation & $0.5551 * * *(0.0305)$ & $0.3295 * * *(0.0289)$ & $-0.0481 * * *(0.0103)$ & $0.2897 * * *(0.0408)$ \\
\hline Ln Fertilizer & $0.0028 *(0.0015)$ & $-0.0102 * * *(0.0016)$ & $-0.0001(0.0008)$ & $-0.0143 * * *(0.0025)$ \\
\hline Ln Road length & $-0.0021 * *(0.0011)$ & $-0.0061 * * *(0.0016)$ & $0.0007(0.0006)$ & $-0.0039 * *(0.0019)$ \\
\hline Ln Ruliteracy & $-0.0029(0.0058)$ & $0.0226 * * *(0.0073)$ & $0.0016(0.0033)$ & $0.0111(0.0104)$ \\
\hline Ln Tractors & $0.0001(0.0041)$ & $-0.0272 * * *(0.0040)$ & $-0.0030(0.0021)$ & $-0.0093(0.0063)$ \\
\hline Ln Pumpset & $-0.0085 * *(0.0038)$ & $-0.0009(0.0038)$ & $-0.0048 * *(0.0019)$ & $0.0034(0.0060)$ \\
\hline Year & $0.0052 * * *(0.0005)$ & $0.0097 * * *(0.0003)$ & $0.0076^{* * *}(0.0002)$ & $0.0044 * * *(0.0005)$ \\
\hline Constant & $-12.6816 * * *(0.9779)$ & $-20.7909 * * *(0.7631)$ & $-14.2300 * * *(0.3563)$ & $-8.3974 * * *(1.0989)$ \\
\hline District fixedeffects & Yes & Yes & Yes & Yes \\
\hline Observations & 1115 & 1115 & 1115 & 1115 \\
\hline Wald chi2(34) & $9129.79 * * *$ & $5816.67 * * *$ & $9160.47 * * *$ & $181.24 * * *$ \\
\hline $\mathrm{F}(1,24)^{1}$ & $194.478 * * *$ & $6727.63 * * *$ & $25.435 * * *$ & $3.035^{*}$ \\
\hline $\operatorname{chi} 2(25)^{2}$ & 40.45 & 2.44 & 4.02 & 3.46 \\
\hline
\end{tabular}

Note: ${ }^{1}$ Woolridge test for autocorrelation in panel data $\left(\mathrm{H}_{0}\right.$ : no first order auto correlation) and ${ }^{2}$ Modified Wald tests for groupwise heteroscedasticity in cross-sectional time-series FGLS regression model

Significance level: $* \mathrm{p}<0.10,{ }^{* *} \mathrm{p}<0.05,{ }^{* *} \mathrm{p}<0.01$; Figures within the parentheses are standard errors; District dummies were incorporated but the estimated coefficients are not shown.

cross-sectional units was investigated (Greene, 2000). Based on the aforesaid verifications, we applied feasible generalized least squares (FGLS) method with necessary corrections for autocorrelation and heteroscedasticity to estimate model (1), under the assumptions that; within panels, there is AR (1) autocorrelation and that the coefficient of the AR (1) process is common to all the panels. However, it is important to note that FGLS is feasible and tend to produce efficient and consistent estimates of standard errors, provided that $\mathrm{N}<\mathrm{T}$ that is panel time dimensions, $\mathrm{T}$ is larger than the crosssectional dimensions, N (Beck and Katz, 1995; Hoechle, 2007). In our case, this assumption was satisfied as under each ACZ, the number of districts, representing the crosssectional units $(\mathrm{N})$ was less than the time period of 46 years.

The marginal effects of the weather parameters were calculated at their mean values from the regression coefficients (which measure elasticity). Thus, the combined marginal effect of climate variables, viz., rainfall, minimum and maximum temperature on crop yield was quantified using equation (2).
$\frac{\mathrm{dy}}{\mathrm{dc}}=\left(\beta_{\mathrm{MT}} *\left[\frac{\overline{\mathrm{Y}}}{\overline{\overline{\mathrm{MT}}}}\right]+\beta_{\mathrm{MNT}} *\left[\frac{\overline{\mathrm{Y}}}{\overline{\mathrm{MNT}}}\right]+\beta_{\mathrm{R}} *\left[\frac{\overline{\mathrm{Y}}}{\overline{\overline{\mathrm{R}}}}\right]\right) \ldots \ldots . .(2)$

Where, $\frac{d y}{d c}$ is combined marginal effect of change in climate variables on the crop yield, $\beta$ denote coefficients which are determined from the model, $\overline{\mathrm{MT}}$ is mean maximum temperature, $\overline{\mathrm{MNT}}$ is mean minimum temperature, $\overline{\mathrm{R}}$ is mean rainfall, and $\bar{Y}$ is the mean crop yield during the period in an ACZ.

Further, to project the changes in crop yields we used CORDEX South Asia multi-RCM reliabilityensemble average estimate of projected changes in annual mean of daily minimum and maximum temperature over India for the 30 year future periods: near-term (2016-2045), mid-term (2036$65)$ and long-term (2066-2095) changes in future climate over India under RCP 8.5 (worst case scenario), relative to the base 1976-2005.

Further, a variation of 5, 10 and 12 percent in rainfall was assumed during the period of 2030s, 2050s and 2080s. The direction of rainfall variation was based on rainfall trend 
Table 4: Estimated regression coefficients of climate impact on crop yields: Central Plateau \& Hills

\begin{tabular}{|c|c|c|c|c|c|}
\hline Variables & Sorghum & Maize & Groundnut & Wheat & Rapeseed \&Mustard \\
\hline Ln Rainfall & $\begin{array}{l}0.0555 * * * \\
(0.0064)\end{array}$ & $\begin{array}{l}0.0109 \\
(0.0067)\end{array}$ & $\begin{array}{l}0.0474 * * * \\
(0.0059)\end{array}$ & $\begin{array}{l}-0.0037 * * * \\
(0.0006)\end{array}$ & $\begin{array}{l}0.0039 * \\
(0.0022)\end{array}$ \\
\hline Ln Min Temp & $\begin{array}{l}-0.4282 * * * \\
(0.1426)\end{array}$ & $\begin{array}{l}-0.2816^{* * *} \\
(0.0620)\end{array}$ & $\begin{array}{l}0.1792 * * * \\
(0.0612)\end{array}$ & $\begin{array}{l}-0.0782 * * * \\
(0.0205)\end{array}$ & $\begin{array}{l}0.5396 * * * \\
(0.0555)\end{array}$ \\
\hline Ln Max Temp & $\begin{array}{l}0.0131 \\
(0.1234)\end{array}$ & $\begin{array}{l}-0.0315 \\
(0.0382)\end{array}$ & $\begin{array}{l}-0.0385 \\
(0.0379)\end{array}$ & $\begin{array}{l}0.0030 \\
(0.0217)\end{array}$ & $\begin{array}{l}0.1221 * \\
(0.0641)\end{array}$ \\
\hline Ln Irrigation & $\begin{array}{l}0.4574 * * * \\
(0.1187)\end{array}$ & $\begin{array}{l}0.3648^{* * *} \\
(0.0229)\end{array}$ & $\begin{array}{l}0.4258^{* * *} \\
(0.0192)\end{array}$ & $\begin{array}{l}-0.0744 * * * \\
(0.0104)\end{array}$ & $\begin{array}{l}0.0493 * * * \\
(0.0152)\end{array}$ \\
\hline Ln Fertilizer & $\begin{array}{l}0.0076 * * \\
(0.0035)\end{array}$ & $\begin{array}{l}-0.0069^{* * *} \\
(0.0011)\end{array}$ & $\begin{array}{l}-0.0013 \\
(0.0011)\end{array}$ & $\begin{array}{l}0.0014 * * \\
(0.0006)\end{array}$ & $\begin{array}{l}0.0106 * * * \\
(0.0016)\end{array}$ \\
\hline Ln Road length & $\begin{array}{l}0.0024 \\
(0.0029)\end{array}$ & $\begin{array}{l}-0.0017 \\
(0.0011)\end{array}$ & $\begin{array}{l}-0.0008 \\
(0.0011)\end{array}$ & $\begin{array}{l}-0.0012 * * * \\
(0.0005)\end{array}$ & $\begin{array}{l}0.0012 \\
(0.0016)\end{array}$ \\
\hline Ln Ruliteracy & $\begin{array}{l}-0.0150 \\
(0.0097)\end{array}$ & $\begin{array}{l}-0.0113 * * * \\
(0.0032)\end{array}$ & $\begin{array}{l}-0.0007 \\
(0.0030)\end{array}$ & $\begin{array}{l}-0.0019 \\
(0.0017)\end{array}$ & $\begin{array}{l}0.0162 * * * \\
(0.0045)\end{array}$ \\
\hline Ln Tractors & $\begin{array}{l}-0.0230 * * * \\
(0.0046)\end{array}$ & $\begin{array}{l}0.0042 * * * \\
(0.0015)\end{array}$ & $\begin{array}{l}0.0039 * * * \\
(0.0014)\end{array}$ & $\begin{array}{l}0.0002 \\
(0.0008)\end{array}$ & $\begin{array}{l}0.0025 \\
(0.0021)\end{array}$ \\
\hline Ln Pumpset & $\begin{array}{l}-0.0374 * * * \\
(0.0096)\end{array}$ & $\begin{array}{l}-0.0263 * * * \\
(0.0033)\end{array}$ & $\begin{array}{l}-0.0039 \\
(0.0030)\end{array}$ & $\begin{array}{l}-0.0032 \\
(0.0018)\end{array}$ & $\begin{array}{l}0.0425 * * * \\
(0.0045)\end{array}$ \\
\hline Year & $\begin{array}{l}0.0061 * * * \\
(0.0007)\end{array}$ & $\begin{array}{l}0.0093 * * * \\
(0.0003)\end{array}$ & $\begin{array}{l}0.0036^{* * *} \\
(0.0002)\end{array}$ & $\begin{array}{l}0.0080 * * * \\
(0.0002)\end{array}$ & $\begin{array}{l}0.0104 * * * \\
(0.0004)\end{array}$ \\
\hline Constant & $\begin{array}{l}-11.1709 * * * \\
(1.1990)\end{array}$ & $\begin{array}{l}-18.1701 * * * \\
(0.4701)\end{array}$ & $\begin{array}{l}-8.9257 * * * \\
(0.3845)\end{array}$ & $\begin{array}{l}-14.7856^{* * *} \\
(0.3099)\end{array}$ & $\begin{array}{l}-23.2314^{* * * *} \\
(0.7984)\end{array}$ \\
\hline District fixedeffects & Yes & Yes & Yes & Yes & Yes \\
\hline Observations & 1729 & 1729 & 1729 & 1729 & 1729 \\
\hline Wald chi2(50) & $228.37 * * *$ & $10923.51 * * *$ & $3557.93 * * *$ & $15695.24 * * *$ & $10832.09 * * *$ \\
\hline $\mathrm{F}(1,40)^{1}$ & $1429.077 * * *$ & $8638.566^{* * *}$ & $1523.778 * * *$ & $7.87 * * *$ & $5339.083 * * *$ \\
\hline $\operatorname{chi} 2(41)^{2}$ & 11.16 & 6.87 & 3.44 & 2.26 & 2.46 \\
\hline
\end{tabular}

Note: ${ }^{1}$ Woolridge test for autocorrelation in panel data $\left(\mathrm{H}_{0}\right.$ : no first order auto correlation) and ${ }^{2}$ Modified Wald tests for groupwise heteroscedasticity in cross-sectional time-series FGLS regression model

Significance level: ${ }^{*} \mathrm{p}<0.10,{ }^{* *} \mathrm{p}<0.05,{ }^{* * *} \mathrm{p}<0.01$; Figures within the parentheses are standard errors; District dummies were incorporated but the estimated coefficients are not shown

during the period from 2001-2011 for each of the ACZ. The projected impact of climate change on crop yield expressed as percentage change was calculated using equation (3),

$$
\Delta \mathrm{Y}=\left(\frac{\partial \mathrm{Y}}{\partial \mathrm{R}}\right) * \Delta \mathrm{R}+\left(\frac{\partial \mathrm{Y}}{\partial \mathrm{T}}\right) * \Delta \mathrm{T} * 100 \ldots .(3)
$$

Where, $\Delta \mathrm{Y}$ denotes change in crop yield, $\Delta \mathrm{R}$ in rainfall and $\Delta \mathrm{T}$ in temperature and $\left(\frac{\partial Y}{\partial R}\right)$ and $\left(\frac{\partial Y}{\partial T}\right)$ are their marginal effects.

\section{RESULTS AND DISCUSSION}

\section{Eastern Plateau \& Hills Region}

As shown in Table3, rise in minimum temperature lowers all the crop yields, with are latively strongerimpact on linseed yield. On the other hand, higher maximum temperature adversely impacted rice yield only. Rainfall appears to benefit productivity of rice and linseed while it negatively affects wheat and maize yield. Irrigation variable is highly significant and increase yield of all the crops, except that of wheat. 
Table 5: Estimated regression coefficients of climate impact on crop yields; Western Plateau \& Hills

\begin{tabular}{|c|c|c|c|c|c|}
\hline Variables & Sorghum & Cotton & Sugarcane & Wheat & Rapeseed \& Mustard \\
\hline Ln Rainfall & $\begin{array}{l}0.0669 * * * \\
(0.0076)\end{array}$ & $\begin{array}{l}0.0214 * \\
(0.0124)\end{array}$ & $\begin{array}{l}0.0070 \\
(0.0051)\end{array}$ & $\begin{array}{c}-0.0020 * * \\
(0.0008)\end{array}$ & $\begin{array}{l}0.0187 * * * \\
(0.0031)\end{array}$ \\
\hline Ln Min Temp & $\begin{array}{l}-0.2867 * * \\
(0.1413)\end{array}$ & $\begin{array}{l}-0.6749 * * \\
(0.3060)\end{array}$ & $\begin{array}{l}0.0026 \\
(0.0336)\end{array}$ & $\begin{array}{l}0.0034 \\
(0.0085)\end{array}$ & $\begin{array}{l}0.4826 * * * \\
(0.0974)\end{array}$ \\
\hline Ln Max Temp & $\begin{array}{l}1.1945 * * * \\
(0.3889)\end{array}$ & $\begin{array}{l}-1.2066^{* * *} \\
(0.4701)\end{array}$ & $\begin{array}{l}-0.1796 \\
(0.1397)\end{array}$ & $\begin{array}{l}-0.1308^{* * *} \\
(0.0491)\end{array}$ & $\begin{array}{l}-1.7212 * * * \\
(0.2308)\end{array}$ \\
\hline Ln Irrigation & $\begin{array}{l}0.6910^{* * *} \\
(0.1389)\end{array}$ & $\begin{array}{l}0.4579 * * * \\
(0.0799)\end{array}$ & $\begin{array}{l}-0.0466^{*} \\
(0.0266)\end{array}$ & $\begin{array}{l}-0.0640 * * * \\
(0.0141)\end{array}$ & $\begin{array}{l}0.0548 * * * \\
(0.0180)\end{array}$ \\
\hline Ln Fertilizer & $\begin{array}{l}0.0319 * * * \\
(0.0028)\end{array}$ & $\begin{array}{l}0.0293 * * * \\
(0.0048)\end{array}$ & $\begin{array}{l}-0.0066^{* * *} \\
(0.0016)\end{array}$ & $\begin{array}{l}0.0028 * * * \\
(0.0006)\end{array}$ & $\begin{array}{l}-0.0111 * * * \\
(0.0017)\end{array}$ \\
\hline Ln Road length & $\begin{array}{l}0.0041 \\
(0.0028)\end{array}$ & $\begin{array}{l}-0.0008 \\
(0.0022)\end{array}$ & $\begin{array}{l}-0.0011 \\
(0.0009)\end{array}$ & $\begin{array}{l}-0.0001 \\
(0.0005)\end{array}$ & $\begin{array}{l}-0.0028 \\
(0.0018)\end{array}$ \\
\hline Ln Ruliteracy & $\begin{array}{l}-0.0475 \\
(0.0316)\end{array}$ & $\begin{array}{l}-0.3287 * * * \\
(0.0815)\end{array}$ & $\begin{array}{l}-0.0595 * * * \\
(0.0219)\end{array}$ & $\begin{array}{l}-0.0162 * * \\
(0.0074)\end{array}$ & $\begin{array}{l}0.0027 \\
(0.0182)\end{array}$ \\
\hline Ln Tractors & $\begin{array}{l}-0.0381 * * * \\
(0.0067)\end{array}$ & $\begin{array}{l}-0.0283 * * \\
(0.0133)\end{array}$ & $\begin{array}{l}-0.0004 \\
(0.0041)\end{array}$ & $\begin{array}{l}-0.0014 \\
(0.0015)\end{array}$ & $\begin{array}{l}0.0042 \\
(0.0039)\end{array}$ \\
\hline Ln Pumpset & $\begin{array}{l}0.0072 \\
(0.0065)\end{array}$ & $\begin{array}{l}0.0140 \\
(0.0102)\end{array}$ & $\begin{array}{l}-0.0120 * * * \\
(0.0035)\end{array}$ & $\begin{array}{l}0.0024 \\
(0.0015)\end{array}$ & $\begin{array}{l}-0.0182 * * * \\
(0.0038)\end{array}$ \\
\hline Year & $\begin{array}{l}0.0073 * * * \\
(0.0016)\end{array}$ & $\begin{array}{l}0.0449 * * * \\
(0.0039)\end{array}$ & $\begin{array}{l}0.0121 * * * \\
(0.0011)\end{array}$ & $\begin{array}{l}0.0086^{* * *} \\
(0.0004)\end{array}$ & $\begin{array}{l}0.0134 * * * \\
(0.0010)\end{array}$ \\
\hline Constant & $\begin{array}{l}-18.5905^{* * *} \\
(3.1000)\end{array}$ & $\begin{array}{l}-92.5630 * * * \\
(7.3605)\end{array}$ & $\begin{array}{l}-21.1204 * * * \\
(2.1160)\end{array}$ & $\begin{array}{l}-16.4440 * * * \\
(0.8069)\end{array}$ & $\begin{array}{l}-22.4462 \\
(1.9298)\end{array}$ \\
\hline District fixedeffects & Yes & Yes & Yes & Yes & Yes \\
\hline Observations & 1255 & 1255 & 1255 & 1253 & 1228 \\
\hline Wald chi2(39) & $439.87 * * *$ & $1393.01 * * *$ & $17146.177 * * *$ & $10134.02 * * *$ & $6572.16^{* * *}$ \\
\hline $\mathrm{F}(1,29)^{1}$ & $3483.519 * * *$ & $4015.193 * * *$ & & $11.343 * * *$ & $6918.301 * * *$ \\
\hline $\operatorname{chi} 2(30)^{2}$ & 13.79 & 1 & 6.51 & 1.55 & 4.3 \\
\hline
\end{tabular}

Note: ${ }^{1}$ Woolridge test for autocorrelation in panel data $\left(\mathrm{H}_{0}\right.$ : no first order auto correlation) and ${ }^{2}$ Modified Wald tests for groupwise heteroscedasticity in cross-sectional time-series FGLS regression model

Significance level: ${ }^{*} \mathrm{p}<0.10,{ }^{* *} \mathrm{p}<0.05,{ }^{* * *} \mathrm{p}<0.01$; Figures within the parentheses are standard errors; District dummies were incorporated but the estimated coefficients are not shown.

\section{Central Plateau \& Hills Region}

The estimated regression results presented in Table 4 indicate that sorghum, maize, groundnut and rapeseed \& mustard yields are positively affected by higher rainfall. Rise in minimum temperature significantly lowers the yield of sorghum, maize and wheat, while higher maximum temperature adversely impacts maize and groundnut yields. Fertilizer consumption increases yield of sorghum, wheat and rapeseed \& mustard. Higher irrigation appears to significantly benefit all the crop yields except that of wheat in the zone.

\section{Western Plateau \& Hills Region}

Cotton, sugarcane, wheat and rapeseed \&mustard yield are adversely impacted by higher maximum temperature (Table 5). Rise in minimum temperature had a negative effect on sorghum and cotton yield. Higher rainfall benefits all crop yields except wheat. Input variables such as irrigation and fertilizer,increases yield of sorghum, cotton and rapeseed $\&$ mustard where as it decrease yield of sugarcane. 
Table 6: Estimated regression coefficients of climate impact on crop yields; Southern Plateau \& Hills

\begin{tabular}{|c|c|c|c|c|}
\hline Variables & Rice & Groundnut & Wheat & Linseed \\
\hline Ln Rainfall & $-0.0292 * * *(0.0046)$ & $0.0495 * * *(0.0068)$ & $-0.0077 * * *(0.0016)$ & $0.0098 *(0.0050)$ \\
\hline Ln Min Temp & $-0.0694(0.1041)$ & $-0.5207 * * *(0.1504)$ & $-0.0532(0.0711)$ & $-0.1999(0.2180)$ \\
\hline Ln Max Temp & $-0.1602(0.1060)$ & $0.1408(0.1628)$ & $-0.1208(0.1133)$ & $-1.1369 * * *(0.3481)$ \\
\hline Ln Irrigation & $0.8885 * * *(0.0282)$ & $0.4835^{* * *}(0.0252)$ & $-0.0591 * * *(0.0137)$ & $0.2374 * * *(0.0356)$ \\
\hline LnFertilizer & $0.0024(0.0031)$ & $-0.0133 * * *(0.0040)$ & $0.0064 * * *(0.0021)$ & $-0.0280 * * *(0.0062)$ \\
\hline Ln Road length & $-0.0046^{* * *}(0.0011)$ & $-0.0032 * *(0.0016)$ & $0.0000(0.0007)$ & $0.0091 * * *(0.0021)$ \\
\hline Ln Ruliteracy & $-0.0004(0.0049)$ & $0.0113 *(0.0061)$ & $-0.0072 * *(0.0033)$ & $-0.0009(0.0102)$ \\
\hline Ln Tractors & $0.0121 * * *(0.0027)$ & $-0.0035(0.0031)$ & $-0.0111 * * *(0.0019)$ & $-0.0501 * * *(0.0054)$ \\
\hline Ln Pumpset & $0.0081 * * *(0.0029)$ & $-0.0046(0.0037)$ & $-0.0110 * * *(0.0021)$ & $-0.0371 * * *(0.0060)$ \\
\hline Year & $-0.0012 * * *(0.0005)$ & $0.0045^{* * *}(0.0004)$ & $0.0088 * * *(0.0002)$ & $0.0101 * * *(0.0007)$ \\
\hline Constant & $-1.9309 * *(0.8512)$ & $-9.1495 * * *(0.8288)$ & $-15.8455 * * *(0.4787)$ & $-15.8353 * * *(1.4634)$ \\
\hline District fixedeffects & Yes & Yes & Yes & Yes \\
\hline Observations & 1347 & 1347 & 1347 & 1347 \\
\hline Wald chi2(39) & $26103.87 * * *$ & 2685.03 & $12498.97 * * *$ & $388.83 * * *$ \\
\hline$F(1,29)^{1}$ & $6469.315 * * *$ & $323.057 * * *$ & $51.145 * * *$ & $53.662 * * *$ \\
\hline $\operatorname{chi} 2(30)^{2}$ & 0.98 & 3.96 & 1.81 & 6.91 \\
\hline
\end{tabular}

Note: ${ }^{1}$ Woolridge test for autocorrelation in panel data $\left(\mathrm{H}_{0}\right.$ : no first order auto correlation) and ${ }^{2}$ Modified Wald tests for groupwise heteroscedasticity in cross-sectional time-series FGLS regression model

Significance level: ${ }^{*} \mathrm{p}<0.10,{ }^{* *} \mathrm{p}<0.05, * * * \mathrm{p}<0.01$; Figures within the parentheses are standard errors; District dummies were incorporated but the estimated coefficients are not shown.

\section{Southern Plateau \& Hills Region}

As shown in Table6, both higher rainfall and temperature lower yield of rice. Moreover groundnut, wheat and linseed yields are also negatively impacted by higher maximum temperature. Rice, groundnut and linseed yields are positively and significantly affected by irrigation. On the other hand, the input variable fertilizer benefits rice and wheat yield only.

\section{Marginal effects (1966-2011) and Projections for kharif crop yields}

During the period from 1966-2011, a decline of 0.72 percent in rice yield was observed in Southern Plateau \& Hills. As shown in Table 6, maize yield declined in Central Plateau \& Hills (1.33 percent). The maximum reduction in groundnut occurred in Southern Plateau \& Hills (covering parts of Andhra Pradesh, Karnataka and Tamil Nadu), whereas in Central Plateau \& Hills it showed an increase of 0.55 percent. Wide variations were observed in sorghum yield which showed a decline of 4.54 percent in Central Plateau $\&$ Hills (covering parts of Madhya Pradesh, Rajasthan and
Uttar Pradesh) and increase of 4.68 percent in Western Plateau \& Hills (parts of Madhya Pradesh and Maharashtra). The yield loss for sugarcane was to the extent 3.66 percent in Western Plateau \& Hills, respectively. Further, the effect of climatic variations has been found to be negative for cotton in Western Plateau \& Hills and Trans-Gangetic Plains, where yield reduced by 1.74 and 0.59 percent.

As shown in Table 7, by 2050s maize yield is expected to reduce by 3.33 percent in Central Plateau \& Hills. In Western Plateau \& Hills, cotton yield is expected to decline by 4.19 and 7.18 percent under by 2050 s and 2080 s. By the end of the century, sorghum yield is projected to decline up to 19 percent in Central Plateau \& Hills. While on the other hand, for the similar period it will increase by about 18 percent in Western Plateau \& Hills. Moreover, in Western Plateau \& Hills the sugarcane yield will reduce by 6.38 percent by 2040s. The productivity of groundnut is likely to decline by 6.62 percent Southern Plateau \& Hills by 2080s. 
Table 7: Projected changes for Kharifcrop yields by $2030,2050 \& 2080$ s

\begin{tabular}{llllll}
\hline Agro-climatic Zone & Crops & Marginal & $2030 \mathrm{~s}$ & $2050 \mathrm{~s}$ & $2080 \mathrm{~s}$ \\
& & Effects & $\Delta \mathrm{MinT}=1.50$ & $\Delta \mathrm{MinT}=2.60$ & $\Delta \mathrm{MinT}=4.43$ \\
& & & $\Delta \mathrm{MaxT}=1.36$ & $\Delta \mathrm{MaxT}=2.30$ & $\Delta \mathrm{MaxT}=3.94$ \\
\hline Eastern Plateau \& Hills & Rice & -0.67 & -1.16 & -2.03 & -3.27 \\
& Maize & 0.28 & 0.29 & 0.46 & 0.78 \\
Central Plateau \& Hills & Sorghum & -4.54 & -6.35 & -10.87 & -19.08 \\
& Maize & -1.33 & -1.93 & -3.33 & -5.73 \\
& Groundnut & 0.55 & 1.03 & 1.84 & 2.95 \\
Western Plateau \& Hills & Sorghum & 4.68 & 6.47 & 10.93 & 18.13 \\
& Cotton & -1.74 & -2.45 & -4.19 & -7.18 \\
& Sugarcane & -3.66 & -4.75 & -7.97 & -13.87 \\
Southern Plateau \& Hills & Rice & -0.72 & -1.14 & -1.99 & -3.27 \\
& Groundnut & -1.56 & -2.19 & -3.77 & -6.62 \\
\hline
\end{tabular}

Source: Authors estimation

Note: Direction of rainfall for the future projections was premised on trend analysis for the period, 2001-2011.

Table 8: Projected changes for rabi crop yields by 2030, $2050 \& 2080$ s

\begin{tabular}{|c|c|c|c|c|c|}
\hline \multirow[t]{4}{*}{ Agro-climatic Zone } & \multirow[t]{4}{*}{ Crops } & Marginal & $2030 \mathrm{~s}$ & $2050 \mathrm{~s}$ & $2080 \mathrm{~s}$ \\
\hline & & \multirow[t]{3}{*}{ Effects } & $\Delta \mathrm{MinT}=1.50$ & $\Delta \mathrm{MinT}=2.60$ & $\Delta \mathrm{MinT}=4.43$ \\
\hline & & & $\Delta \mathrm{MaxT}=1.36$ & $\Delta \mathrm{MaxT}=2.30$ & $\Delta \mathrm{MaxT}=3.94$ \\
\hline & & & $\Delta \mathrm{R}=(+/-) 5 \%$ & $\Delta \mathrm{R}=(+/-) 10 \%$ & $\Delta \mathrm{R}=(+/-) 12 \%$ \\
\hline \multirow[t]{2}{*}{ Eastern Plateau \& Hills } & Wheat & -0.26 & -0.34 & -0.59 & -1.07 \\
\hline & Linseed & -0.87 & -1.36 & -2.39 & -4.04 \\
\hline \multirow[t]{2}{*}{ Central Plateau \& Hills } & Wheat & -0.94 & -1.44 & -2.50 & -4.22 \\
\hline & \multicolumn{2}{|c|}{ Rapeseed \& Mustard } & 2.73 & 4.06 & $\begin{array}{ll}7.03 & 11.97\end{array}$ \\
\hline \multirow[t]{2}{*}{ Western Plateau \& Hills } & Wheat & -0.88 & -1.21 & -2.05 & -3.49 \\
\hline & \multicolumn{2}{|c|}{ Rapeseed \& Mustard } & -1.86 & -2.13 & $-3.44-6.01$ \\
\hline \multirow[t]{2}{*}{ Southern Plateau \& Hills } & Wheat & -1.27 & -1.88 & -3.23 & -5.44 \\
\hline & Linseed & -1.35 & -1.86 & -3.16 & -4.88 \\
\hline
\end{tabular}

Source: Authors estimation

Note: Direction of rainfall for the future projections was premised on trend analysis for the period, 2001-2011.

\section{Marginal effects (1966-2011) and projections forrabi crop yields}

The results reveal that in Central Plateau \& Hills, rapeseed \& mustard yield was highly benefitted from climate variations, where yield showed anincrease of 2.73 percent during the period 1966-2011 (Table 8). On the other spectrum, the rapeseed \&mustard yield reduced by 1.86 percent in
Western Plateau \& Hills. Yield loss in case of wheat seems to be marginal in the growing regions. During the period, linseed declined by 1.35 and 0.87 percent in both the Eastern and Southern Plateau \& Hills, respectively.

The projected impact of climate change for $r a b i$ crop yields revealed that by 2080 s, wheat yield is projected to decline by 5.44, 3.49 and 4.22 in Southern, Westernand 
Central Plateau\& Hills, respectively. By the end of the century, the rapeseed \& mustard yield is expected to increase by about 11-12 percent in Central Plateau \& Hills. On the other hand, by 2050 s, rapeseed $\&$ mustard yield is likely to reduce by 3.44 percent in Western Plateau \& Hills. In Eastern Plateau \& Hills and Southern Plateau \& Hills, Linseed yield is expected to decline by 2.39 and 3.16 percent by 2050s.

\section{CONCLUSION}

In this study we tried to explore the impact of climate change on crop yields at spatially disaggregated scale using ACZ classification in the Plateau Region. Our findings revealthat most of the kharif and rabi crop yields were adversely impacted by climatic changes across the zones during the period 1966-2011. In analysing the combined marginal effects of climate variables, it was found that rainfall had a positive effect on most of crop yields, but was not adequate to counter balance the combined impacts of change in maximum and minimum temperatures. Incorporation of socio-economic and technical factors seems to have moderated the degree of potential climate impact on crop yield. The future projections showed reduction in most of crop yields with significant changes in temperature and rainfall. Overall, it is construed that universalapplication of investment strategies for natural resource management and augmentation of agriculture productivity will only partially entail the desired targets of reducing the climate induced vulnerability. Rather there is an immense need to formulate regionally tailored adaptation practices to enhance resilience of agricultural system to withstand the climatic shocks (Singh et al, 2014, 2018). Further, improved awareness of climate change at the farm level, is crucial for taking informed decision.Techniques such as solar pumps, drip irrigation and sprinklers must be scaled upfor greater water use efficiency. In addition, climate exposure can be further moderated with diversification to non-farm activities and enhancing the reach and accessibility of insurance covers across regions. Besides, mainstreaming climate adaptation is essential for development of farmer centric climate adaptation and mitigation policy.

\section{Limitations of the study}

First, the sensitivity of crop yields was examined, assuming linear climate-crop yield relation which might not be true under certain conditions. Such an assumption ignores the incremental impact of climate parameters on crop yields.Second, due to unavailability of future climate estimates at ACZ level, our projections assumed uniform changes in rainfall and temperature across the zones. However, climate variations differ across regions, and thus may influence the nature of climate change projections on crop yields.

\section{REFERENCES}

Bal, S.K. and Minhas, P.S. (2017). Atmospheric Stressors: Challenges and Coping Strategies. In: 'Abiotic Stress Management for ResilientAgriculture'.(Eds. P.S. Minhas et al.). 9-50, Springer Nature Singapore Pte. Ltd.

Balvanshi,A. and Tiwari, H.L. (2019). Mitigating future climate change effects on wheat and soybean yields in central region of Madhya Pradesh by shifting sowing dates. $J$. Agrometeorol., 21 (4): 468-473.

Beck, N. and Katz, J.N. (1995). What to do (and not to do) with time-series cross-section data. Amer. Pol. Sci.Rev., 89(3): 634-647.

Drukker, D.M. (2003). Testing for serial correlation in linear panel-data models. The Stata Jn., 3(2):168-177.

Greene, W. (2000). Econometric Analysis. Upper Saddle River, NJ: Prentice-Hall.

Guiteras, R. (2009). The impact of climate change on Indian agriculture.Manuscript, Department of Economics, University of Maryland, College Park, Maryland.

Hoechle, D. (2007). Robust standard errors for panel regressions with cross-sectional dependence. The Stata Jn., 7(3): 281-312.

Jalota, S.K., Kaur, H., Ray, S.S., Tripathy, R., Vashisht, B.B. and Bal, S.K. (2013). Past and General Circulation Modeldriven future trends of climate change in Central Indian Punjab: ensuing yield of rice-wheat cropping system. Current Sci., 104(1): 105-110

MoEF (2017). Climate Change over India: An Interim Report, Eds. Krishnan R., and SanjayJ. ESSO-Indian Institute of Tropical Meteorology, Ministry of Earth Sciences, Government of India, Pune.

Nelson, G.C., Rosegrant, M.W., Palazzo, A., Gray, I., Ingersoll, C., Robertson, R., Tokgoz, S., Zhu, T., Sulser, T. and Ringler, C. (2010). Food Security, Farming and Climate Change to 2050. Research Monograph, International Food Policy Research Institute. Washington, DC.

Singh, P. (2006). Agro-Climatic Zonal Planning Including Agriculture Development in North-Eastern India. Final Report of the Working Group on agriculture XI five-year 
Plan (2007-2012), two volumes, Volume I Main Report. Planning Commission, Government of India, New Delhi.

Singh, N.P., Anand, B., Singh, S. and Khan, M.A. (2019). Mainstreaming climate adaptation in Indian rural developmental agenda: A micro-macro convergence. Clim. Risk Manage., 24, 30-41.
Singh, N.P., Bantilan, C. and Byjesh, K. (2014). Vulnerability and policy relevance to drought in the semi-arid tropics of Asia - A retrospective analysis. Weath. Clim. Extr., 3, 54-61.

Singh, N.P., Singh, S., Anand, B. and Ranjith, PC. (2019). Assessing the impact of climate change on crop yields in Gangetic Plains Region, India. J. Agrometeorol, 21(4),452-461. 